Research, part of a Special Feature on Ecological Restoration in Northern Regions

\title{
Preferences of Local People for the Use of Peatlands: the Case of the Richest Peatland Region in Finland
}

\author{
Anne Tolvanen $^{1,2}$, Artti Juutinen $^{1,2,3}$ and Rauli Svento $^{3}$
}

\begin{abstract}
We analyze the potential for socioeconomically sustainable peatland use by investigating conflicting interests, revealing trade-offs that people are willing to accept, and studying whether opinions are dependent on socioeconomic and demographic factors. Opinions toward five forms of peatland use and seven peatland ecosystem services were surveyed in Northern Ostrobothnia in northern Finland in 2011. Choice experiment (CE) was used to reveal trade-offs in land use preferences, and groups of respondents were identified using the latent class model (LCM). We identified three classes of respondents in which environmentalists showed a high preference toward the cessation of peat production and increase of peatland restoration, the production-oriented class preferred an increase in timber and peat production areas, and the current use supporters agreed on the present land use policy. However, all respondent classes agreed on the increase of nature protection and the present level of timber production and disagreed on the cessation of restoration. The CE revealed that environmentally minded people who are likely to consider the indirect use values and existence values important are less willing to make trade-offs between ecosystem services than those who emphasize direct use values. Because peatland restoration occurs in commercially unproductive peatlands, it improves both the direct use and existence values without reducing provisioning services of peatlands. Therefore, restoration is commonly accepted by the public, in contrast to management options that involve clear trade-offs between ecosystem services. We conclude that the understanding of preferences and trade-offs can enhance sustainable land use planning. It may be unrealistic, however, to expect a solution that all interest groups would completely accept.
\end{abstract}

Key Words: choice experiment; conflict management; ecosystem services; land use management

\section{INTRODUCTION}

The ecosystem service concept and the valuation efforts of ecosystem services are changing the discussion concerning land use policy and natural resource management (Costanza et al. 1997, de Groot et al. 2010). Increasing knowledge on the importance of healthy ecosystems for human well-being is leading to situations in which multifunctional and ecologically sustainable land use is seen as an option to simultaneously generate ecological, social, and economic benefits (e.g., Balmford et al. 2002, de Groot 2006). Valuation of ecosystem services has been done using several methods (e.g., Boyer and Polasky 2004, Brander et al. 2006), whereby the most recently developed technique is the Choice Experiment (CE) method. Besides placing a direct monetary value on ecosystem services, CE can be utilized to investigate factors that determine the demand for ecosystem services because CE reveals trade-offs that people are willing to accept. Trade-offs can be, for example, hypothetical land use options, in which people simultaneously win and lose some benefits such as environmental health, recreation opportunities, or employment. The identification of trade-offs may help in finding possibilities to build consensus and solve conflicts.

Peatlands are widely utilized peat-forming wetland ecosystems throughout the world. They provide a variety of ecosystem services such as timber, peat, carbon sequestration, flood risk reduction, water quality improvement, biodiversity, and recreational benefits (e.g., Zedler and Kercher 2005). The commercial use of peatlands is principally seen to be in conflict with ecological, environmental, and recreational values because large-scale drainage for, e.g., agriculture, forestry, and construction purposes has resulted in deterioration of peatland habitats, the loss of biodiversity, large-scale hydrological problems, and increased emissions of greenhouse gases (Chapman et al. 2003). In Europe, peat has ceased to accumulate within over $50 \%$ of the former mire areas, and almost $20 \%$ of the original peatland areas no longer exist as peatland (Joosten and Clarke 2002). In Finland, the peatland-richest country in the world, about $50 \%$ of the peatland area has been drained for forestry use, 76,000 hectares (less than 1\%) are being used for peat production, and 13\% is protected (Finnish Forest Research Institute 2011). The growing public interest in safeguarding peatland biodiversity and increased knowledge on the capacity of peatlands to retain atmospheric carbon has created a need for peatland restoration. In Finland, restoration is practiced in commercially unproductive forestry-drained peatlands located in or near protected areas. The principal methods are the removal of excess tree stand grown after drainage and the blocking of drainage ditches, which aim at accelerating the peatland succession. Hydrology and peat mineralization and decomposition rates have been observed to regenerate quickly to the level of undrained peatlands, whereas the vegetation succession is slower (Laine et al. 2011, Tarvainen et al. 2012). 
Increasing public awareness calls for the consideration of people's opinions in peatland management, although relatively few scientific studies exist on this topic. In Ireland, sociological methods give promising results on the potential of public participation to reduce conflicts concerning after-use and rehabilitation of peatlands after peat production (Collier and Scott 2008, 2010, Collier 2011). In Finland, a survey sent to landowners and peat industry professionals emphasized an increasing need for discussions between the stakeholders (Selin 1999). To our knowledge, CE has not been used to value the benefits of peatlands, whereas in wetlands, where commercial timber and peat production are not relevant land use options, CE studies have focused solely on management options to maintain the quality and extent of wetlands (Morrison et al. 1999, Carlsson et al. 2003, Birol et al. 2006, Birol and Cox 2007, Westerberg et al. 2010).

We present results from a survey that was part of a regional peatland program in Northern Finland. The program aims at fitting peatland management options into the regional plan and it follows the principles presented in the Finnish Government Program for the Sustainable Use of Mires and Peatlands launched in 2012. We investigated residents' opinions toward five peatland use options: timber production, peat production, protection, restoration, and recreation. Our aim was to analyze the potential for socioeconomically sustainable peatland use by investigating conflicting interests, by revealing trade-offs that people are willing to accept, and by studying whether opinions are dependent on socioeconomic and demographic factors. CE was used to reveal trade-offs in land use preferences, and the groups of respondents were identified using a latent class model (LCM). We expected that the grouping of respondents into different interest groups based on the LCM would reflect the present level of socioeconomical sustainability in peatland use because in CE the respondents had to choose between present and potential future scenarios of peatland use. Based on the results, we discuss factors increasing the socioeconomical sustainability of peatland use.

\section{METHODS}

\section{Survey design}

Opinions of people concerning future scenarios of peatland use were asked using a questionnaire. We initially included five peatland use options: timber production, peat production, protection, restoration, and recreation. The CE was used to assess respondents' preferences for these five options (Louviere et al. 2000). The CE captures both use and nonuse values of ecosystem services. Use values can be direct such as provisioning (energy, employment) or cultural services (recreation); or indirect, such as regulating services (hydrology, flood prevention, carbon sequestration). Nonuse values include existence values, for example supporting ecosystem services such as biodiversity (classification based on Smith et al. 2006). In the CE, respondents were presented with a choice task that included several alternatives, i.e., scenarios in this study, and asked to select the alternative that provides them the highest utility in a hypothetical setting. The alternatives were described using attributes, i.e., the characteristics of the environmental problem in question. The attributes, i.e., peatland use options in this study, were addressed at several levels to find the effect of increase or decrease in the characteristics on people's valuations. Typically, the questionnaire included several choice tasks to get multiple observations for each respondent.

The questionnaire was developed by an expert group representing knowledge on alternative peatland use options. The questionnaire consisted of four parts. The first part contained questions related to respondents' outdoor activities and their attitudes toward ecosystem services provided by peatlands. The second part contained the CE and included descriptions of the attributes, i.e., peatland use options, in terms of timber production, peat production, conservation, restoration, and recreation facilities (Table 1). The attributes and their quantitative levels were identified with information from the expert group. The third part asked respondents' opinions toward statements presented about the significance of nature and peatlands. The fourth part included questions on respondents' socioeconomic background.

To develop the choice tasks presented to respondents in the questionnaire, we applied an orthogonal fractional factorial (main effect) design, which is frequently used in empirical studies (Louviere et al. 2000). This procedure resulted in 12 choice tasks, which were blocked into two groups. ${ }^{[1]}$ Thus, we presented six choice tasks for each respondent and in each task they had to select between three alternatives presenting three peatland use scenarios. Each choice task included two future scenarios and a status quo alternative, in which the levels of attributes refer to the current situation (Table 1). An illustration of a choice task is presented in Fig. 1.

\section{Survey data}

In February 2011, we sent 1250 questionnaires to randomly selected, over 18-years-old inhabitants living in four municipalities in northern Ostrobothnia. We sent 500 questionnaires to Oulu, the largest city of the region, and 250 questionnaires to three rural municipalities in the southern (Siikalatva), northeastern (Pudasjärvi), and eastern (Utajärvi) part of the region. By addressing these mail-based surveys to different municipalities we aimed at covering people living at various socioeconomic situations. Only 192 (15.4\%) mailbased surveys were returned. No reminders were sent, however, because the same survey was simultaneously open to everyone as a web-based survey on the Internet. The link to the web-based survey was advertised through local newspapers, email lists, and in the social media through Facebook and Twitter. The web-based survey received 725 answers. 
Table 1. Attributes (peatland use options) and their levels in the choice tasks with variable names used in the analysis.

\begin{tabular}{|c|c|c|}
\hline Attribute & Level & Variable name ${ }^{\ddagger}$ \\
\hline Timber production area (ha) & $\begin{array}{l}\text { 1. Smaller than present state: } 700,000 \text { ha } \\
\text { 2. Present state: } 800,000 \mathrm{ha}^{\dagger} \\
\text { 3. Larger than present state: } 900,000 \text { ha }\end{array}$ & $\begin{array}{l}\text { Timber }^{-} \\
\text {Timber }^{+}\end{array}$ \\
\hline Peat production area (ha) & $\begin{array}{l}\text { 1. Peat production ceased: } 0 \text { ha, the reduction takes place gradually } \\
\text { as the existing production fields are exhausted } \\
\text { 2. Present state: } 18,000 \mathrm{ha}^{\dagger} \\
\text { 3. Larger than present state: } 22,000 \text { ha }\end{array}$ & $\begin{array}{l}\text { Peat }^{-} \\
\text {Peat }^{+}\end{array}$ \\
\hline Protection area ( $\%$ of peatland area) & $\begin{array}{l}\text { 1. Present state: } 9 \%^{\dagger} \\
\text { 2. Larger than present state: } 10 \% \\
\text { 3. Considerably larger than present state: } 12 \%\end{array}$ & $\begin{array}{l}\text { Protection } \\
\text { Protection } \\
\text { Protection }\end{array}$ \\
\hline Restoration area (ha/year) & $\begin{array}{l}\text { 1. Restoration ceased: } 0 \text { ha/year } \\
\text { 2. Present state: } 150 \text { ha/year } \\
\text { 3. Larger than present state: } 300 \text { ha/year }\end{array}$ & $\begin{array}{l}\text { Restor }^{-} \\
\text {Restor }^{+}\end{array}$ \\
\hline $\begin{array}{l}\text { Recreation facilities (routes, resting } \\
\text { places, information boards) }\end{array}$ & $\begin{array}{l}\text { 1. Less than present state } \\
\text { 2. Present state }{ }^{\dagger} \\
\text { 3. More than present state }\end{array}$ & Recreat $^{-}$ \\
\hline
\end{tabular}

The attribute level describes the basic alternative.

We used dummy coding for the attribute levels in the analysis except that Protection was treated as a continuous variable.

Fig. 1. An example of a choice task including three alternative peatland use scenarios.

\begin{tabular}{|c|c|c|c|}
\hline \multicolumn{4}{|l|}{ Choice task 1.} \\
\hline $\begin{array}{l}\text { Attribute (peatland } \\
\text { use option) }\end{array}$ & Current situation & Peatland use scenario 1 & Peatland use scenario 2 \\
\hline $\begin{array}{l}\text { Timber production } \\
\text { area }\end{array}$ & Present state & $\begin{array}{l}\text { Smaller than present } \\
\text { state }\end{array}$ & Larger than present state \\
\hline $\begin{array}{l}\text { Peat production } \\
\text { area }\end{array}$ & Present state & Larger than present state & Peat production ceased \\
\hline Protection area & Present state & Larger than present state & $\begin{array}{l}\text { Considerably larger than } \\
\text { present state }\end{array}$ \\
\hline Recreation facilities & Present state & Present state & More than present state \\
\hline \multirow[t]{2}{*}{ Restoration area } & Present state & Restoration ceased & Larger than present state \\
\hline & $\stackrel{\Rightarrow}{\Rightarrow}$ & $\Leftrightarrow 0$ & $\Leftrightarrow 0$ \\
\hline ase choose the & ter & e. & \\
\hline
\end{tabular}

Altogether 205 respondents were removed from analyses because they did not answer the CE question (14 respondents) or they always selected the basic alternative (status quo) in the CE (191 respondents), even though they did not truly consider that alternative as the best option. Instead, they revealed some other reasons for their choices, such as "the alternatives were not credible" or "the choice sets were too complex." A CE including several attributes with multiple levels places a large cognitive burden on the respondents, and therefore, it is not surprising that this type of protest answer emerges. A logit model analysis revealed that the probability of a protest answer increased with the age of respondent or if the respondent lived in a rural area. The probability decreased if the respondent had a university degree or the respondent was an entrepreneur or a lower level employee. The final number of respondents was 712 .

\section{Model}

The CE data was analyzed using latent class model (LCM; Boxall and Adamowicz 2002). LCM can be derived from a random utility model, in which the utility function of each respondent is the sum of a deterministic term that can be described as a function of factors that influence respondents' utility, and a random term that is unobservable and stochastic for researchers. Assuming the existence of $S$ classes and that individual $n$ belongs to class $\mathrm{s}(s=1, \ldots, S)$ the unobservable overall utility $U$ of alternative $i$ for a respondent $n$ is represented by:

$$
U_{n i \mid s}=\beta_{s} x_{n i}+\varepsilon_{n i \mid s}
$$

where $\beta_{s}$ is a class-specific vector of utility coefficients of observed variable $x_{n i}$ for respondent $n$ representing his/her preferences. 
Assuming a type I extreme value distribution for $\varepsilon_{n i}$, the logit probability for choosing alternative $i$ conditional on class membership is defined as:

$$
L_{n \mid s}(i)=\frac{\exp \left(\mu_{s}, \beta_{s}, x_{i}\right)}{\sum_{k \in C} \exp \left(\mu_{s}, \beta_{s}, x_{k}\right)}
$$

where $C$ denotes the respondent's choice set and $\mu_{s}$ is a classspecific scale parameter. Next we can define the joint probability $P_{n}(i)$ that individual $n$ belongs to class $s$ and chooses alternative $i$ as follows:

$$
P_{n}(i)=\sum_{s=1}^{S} S_{n s} L_{n \mid s}(i)
$$

where $s_{n k}$ is the membership probability. In the LCM, preference heterogeneity is accounted for by simultaneously assigning individuals into behavioral classes and estimating the choice model. Thus, preferences are assumed to be homogenous within each class, but vary between the classes. Individual-specific variables can be used to estimate the membership probability.

After intensive testing of different model specifications, we decided to exclude the recreation attribute from the final model. The coefficients for the attribute levels for recreation facilities were often not statistically significant and in some cases they had unexpected signs. Note that leaving out this attribute does not cause problems for the estimation because we used orthogonal design. In addition, we treated the protection attribute as a continuous variable in the estimation, because it included two increasing attribute levels in contrast to the other attributes, which included both increasing and decreasing levels, and because the respondents had quite homogenous preferences for peatland protection. We chose a 3-class model, based on a balanced assessment of the adjusted $\mathrm{r}^{2}$, AIC and BIC statistics (Birol et al. 2006). The 3-classes solution provided the best fit to the data: AIC and BIC statistics decreased and adjusted $\mathrm{r}^{2}$ increased as more classes were added to the model, but the changes were much smaller from two to three than from three to four class models.

\section{RESULTS}

\section{Respondent characteristics}

The respondents were on average 44 years old, and $63 \%$ of them were men. The predominant occupational level was employee, composing $58 \%$ of the respondents. The major household monthly income level was 3000-5000 euros, being attained by $31 \%$ of the respondents. This indicates a slightly higher salary level than on average in Finland, where $23 \%$ of inhabitants belong to this level, and the predominant monthly income level is 1000-3000 euros (Official Statistics of Finland 2009). Fifty-three percent of the respondents lived in rural communities or small towns with less than 20,000 inhabitants, and $46 \%$ lived in towns with over 20,000 inhabitants or cities with over 100,000 inhabitants. These values correspond to the average percentages from the region of Northern Ostrobothnia (55\% and $45 \%$, respectively, Official Statistics of Finland 2011a). The respondents had a higher education level than average inhabitants in the region: $69 \%$ had a secondary level education (university or polytechnic), whereas the same education level is reached only by $26 \%$ of the inhabitants in the region (Official Statistics of Finland 2010). The percentage of landowners was on average $56 \%$ in the surveys, whereas the amount of landowners is considerably lower, $10 \%$, in the region as a whole (Official Statistics of Finland 2011b). The respondents were active peatland users: $92 \%$ visited peatlands more than once in a year, and $47 \%$ at least once a month.

The majority of respondents disagreed or strongly disagreed with the options that suggested a larger timber production area $(66 \%)$, larger peat production area $(69 \%)$, or cessation of restoration (74\%) (Fig. 2). On the other hand, the majority agreed or strongly agreed with the options suggesting cessation of peat production $(61 \%)$ or larger protection $(64 \%)$ and restoration $(70 \%)$ areas. To identify the relative importance of the attributes we analyzed what kind of tradeoffs between the attributes the respondents were willing to accept and how their preferences differed between the groups identified by the LCM.

Fig. 2. Distributions of opinions toward attribute levels describing land-use options, used in the latent class model (LCM). Number of respondents $=712$.

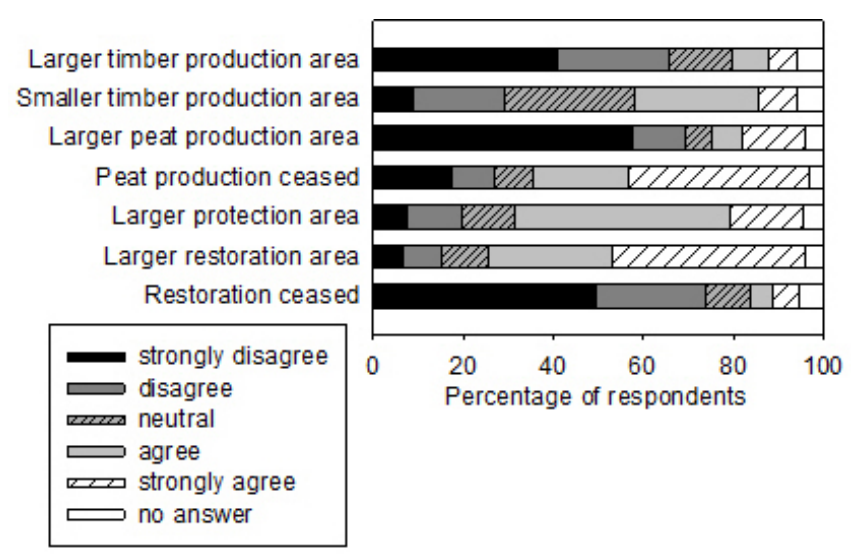

\section{Grouping of respondents}

Based on the preferences toward peatland use options in the $\mathrm{CE}$, the three classes in the LCM were labeled as "environmentalist," "production-oriented," and "current use 
Table 2. Results from the three-class latent class model (LCM) including socioeconomic explanatory variables for class membership. The class membership coefficients for Class 3 were fixed to identify the remaining coefficients. Number of respondents $=712$.

\begin{tabular}{|c|c|c|c|c|c|c|}
\hline & \multicolumn{2}{|c|}{$\begin{array}{c}\text { Class 1: } \\
\text { Environmentalist }\end{array}$} & \multicolumn{2}{|c|}{$\begin{array}{c}\text { Class 2: } \\
\text { Production-oriented }\end{array}$} & \multicolumn{2}{|c|}{$\begin{array}{c}\text { Class 3: } \\
\text { Current use supporter }\end{array}$} \\
\hline & Coeff. & Stand. error & Coeff. & Stand. error & Coeff. & Stand. error \\
\hline Timber $^{+}$ & $* * *-1.387$ & 0.203 & $* * * 0.482$ & 0.155 & 0.353 & 0.216 \\
\hline Timber $^{-}$ & -0.346 & 0.478 & $* * *-1.879$ & 0.319 & $* * *-2.820$ & 0.549 \\
\hline Peat $^{+}$ & $* * *-2.050$ & 0.163 & $* * * 0.985$ & 0.102 & -0.074 & 0.159 \\
\hline Peat $^{-}$ & $* * * 2.811$ & 0.244 & $* * *-1.229$ & 0.153 & $* 0.397$ & 0.227 \\
\hline Protection & $* 0.379$ & 0.206 & $* * * 0.828$ & 0.156 & $* * * 0.756$ & 0.215 \\
\hline Restor $^{+}$ & $* * * 1.629$ & 0.182 & 0.071 & 0.130 & -0.150 & 0.156 \\
\hline Restor $^{-}$ & 0.125 & 0.266 & $* * *-0.882$ & 0.169 & $*_{-}-0.490$ & 0.225 \\
\hline Intercept & 0.223 & 0.253 & 0.242 & 0.178 & $* * * 2.222$ & 0.238 \\
\hline \multicolumn{7}{|l|}{$\begin{array}{l}\text { Class membership } \\
\text { parameters }\end{array}$} \\
\hline Intercept & 0.126 & 0.213 & $* * *-1.386$ & 0.415 & & \\
\hline Residential area & $* * * 0.314$ & 0.065 & 0.000 & 0.001 & & \\
\hline Higher education level & $* * * 1.059$ & 0.265 & -0.013 & 0.353 & & \\
\hline Agric. entrepreneur & $* *-1.297$ & 0.652 & -0.183 & 0.647 & & \\
\hline Other entrepreneur & 0.226 & 0.499 & $* 1.022$ & 0.561 & & \\
\hline Lower-lever employee & $* 0.458$ & 0.245 & -0.087 & 0.334 & & \\
\hline Landowner & $* * *-0.310$ & 0.066 & -0.005 & 0.013 & & \\
\hline Income & 0.000 & 0.000 & $* * * 0.408$ & 0.097 & & \\
\hline Class probabilities & 0.629 & & 0.180 & & 0.191 & \\
\hline RsqAdj & 0.421 & & & & & \\
\hline Log-likelihood & -2657.570 & & & & & \\
\hline AIC & 1.285 & & & & & \\
\hline $\mathrm{BIC}$ & 1.345 & & & & & \\
\hline
\end{tabular}

supporter" classes (Table 2). The environmentalist was the largest class indicated by the class probability 0.629 . The respondents in this class had a strong preference toward the cessation of peat production. They also responded negatively to the increase in timber production area, but they were likely to accept the current timber production level, because the decrease in timber production was not statistically significant. The environmentalists attached positive values to larger peatland protection and restoration areas.

About one fifth of the respondents (class probability 0.180) were assigned to the production-oriented class (Table 2). In particular, the production-oriented respondents preferred an increase in timber and peat production areas in contrast to the other two classes. However, they also regarded environmental issues as important because they agreed on an increase in peatland protection area and disagreed on the cessation of peatland restoration. The current use supporter class was of a similar size to the production-oriented class (class probability 0.191). Members of the current use supporter class preferred the current level of peatland use, indicated by the statistically significant positive intercept in the LCM (Table 2). They also disagreed on the reduction of timber production area and cessation of restoration. They preferred the cessation of peat production, but this coefficient was only weakly significant. Like the other two classes, current use supporters preferred a larger peatland protection area.

We used respondents' socioeconomic characteristics to explain class memberships (Table 2). Of the tested variables, residential area, highest education level (university degree), agricultural entrepreneur, other entrepreneur, lower-level employee, land owner, and household monthly income before taxes were significant and were therefore used in the model. ${ }^{[2]}$ The environmentalist class was characterized by respondents living in a city, having the highest education level, and being a lower-level employee. They were not likely to be agricultural or forestry entrepreneurs and fewer of them owned land compared with the two other classes. The members of the production-oriented class were often entrepreneurs (not agricultural/forestry) and had a higher monthly income level than the respondents in the two other classes. The most typical residential area of the production-oriented class and current use supporters was rural community. Table 3 shows the 
breakdown of the socioeconomic characteristics by the three classes. The respondents were assigned to one of the three classes on the basis of their largest probability score. The average age of respondents was lower in the environmentalist class (42.2 years) than in the production-oriented and current use supporter classes (48.0 and 46.7 years, respectively). The proportion of men was higher in the production-oriented class (77.2\%) than in the environmentalist and current use supporter classes (57.0\% and 63.3\%, respectively).

Table 3. Percentages of respondents with specific socioeconomic characteristics in Classes 1, 2, and 3, and average household incomes (euros/month) of respondents. Number of respondents $=712$.

\begin{tabular}{lccc}
\hline \hline & $\begin{array}{c}\text { Class 1: } \\
\text { Environmentalist }\end{array}$ & $\begin{array}{c}\text { Class 2: } \\
\text { Production- } \\
\text { oriented }\end{array}$ & $\begin{array}{c}\text { Class 3: } \\
\text { Current use } \\
\text { supporter }\end{array}$ \\
\hline $\begin{array}{l}\text { Most typical residential } \\
\text { area (\%) }\end{array}$ & City, 41.0 & Rural, 20.5 & Rural, 26.6 \\
$\begin{array}{l}\text { Highest education level } \\
(\%)\end{array}$ & 50.4 & 28.3 & 20.1 \\
$\begin{array}{l}\text { Agric. Entrepreneur } \\
\text { (\%) }\end{array}$ & 1.3 & 5.5 & 7.2 \\
$\begin{array}{l}\text { Other entrepreneur (\%) } \\
\begin{array}{l}\text { Lower-lever employee } \\
(\%)\end{array}\end{array}$ & 5.6 & 14.2 & 7.2 \\
$\begin{array}{l}\text { Landowner (\%) } \\
\text { Average income }\end{array}$ & 49.5 & 29.1 & 34.5 \\
\hline
\end{tabular}

\section{Opinions toward peatlands as providers of ecosystem services}

In the questionnaire we asked respondents to rank the importance of ecosystem services in peatlands by using a Likert scale from $1=$ not important to $5=$ very important. Of the seven surveyed ecosystem services, five were significant in the LCM in explaining the class membership of respondents (Table 4): regional employment and income effects (employment and income), hydrological problems due to forestry draining and peat production (hydrological problems), peatlands as sources of energy (energy source), peatlands as habitats for native peatland species (species and habitats), and peatlands as recreation sites (recreation). Flood prevention and carbon sequestration services were considered important or very important by $77 \%$ and $75 \%$ of all respondents, respectively, but because these ecosystem services were not statistically significant in the LCM, they are not shown in Table 4.

Members of the environmentalist class considered regional employment and income and peatlands as sources of energy to be less important factors than did members in the current use supporter class, which was treated as the reference class with fixed class membership coefficients in this LCM (Table 4). ${ }^{[3]}$ In addition, the environmentalist class considered hydrological problems, peatlands as habitats for species, and peatlands as a place for recreation as more important than the other two classes. The production-oriented class was characterized by a higher emphasis on peatlands as sources of energy.

The frequency distributions show that hydrological problems, species and habitats, and recreation were considered important or very important ecosystem services by the majority (95-98\%) of environmentalists (Fig. 3). On the other hand, all five ecosystem services were considered important or very important by the majority $(54-81 \%)$ of production-oriented class and current use supporters, and the least important ecosystem service for them was recreation.

Fig. 3. Opinions considering the ecosystem services of peatlands in the three classes of respondents, significant in the latent class model (LCM). Number of respondents = 712 .

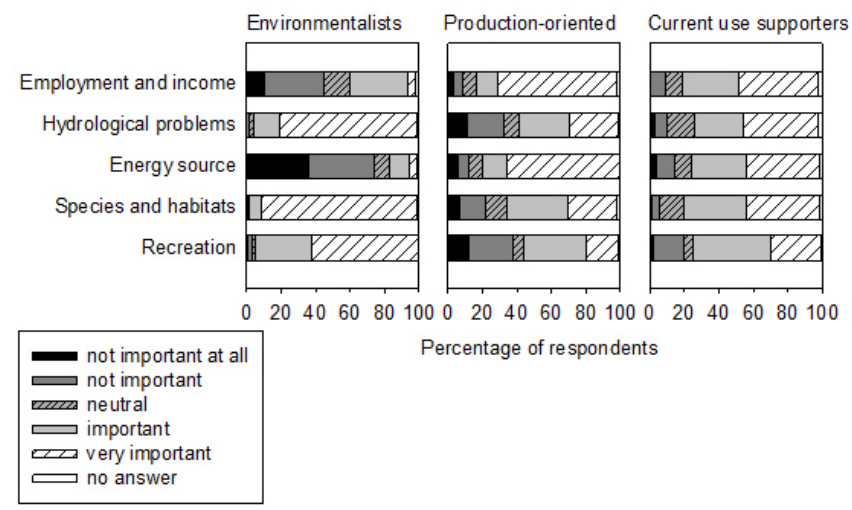

Respondents' attitudes toward nature and peatlands were also incorporated into the LCM (Table 5). The model revealed that the respondents agreeing with the statements that nature provides peaceful and good feelings, peatlands have a right to exist without utilization, and people should have more respect for peatlands belonged likely to the environmentalist class. Furthermore, members of this class disagreed with the statements that peatlands should serve multiple purposes and legislation limits the peatland use too much. In contrast, the latter statement was supported by the respondents belonging to the production-oriented class.

The frequency distributions show the greatest deviation in the opinions concerning the multiple uses of peatlands and the legislation limiting peatland use. The majority ( $64 \%$ and $85 \%$, respectively) of the environmentalists disagreed with these statements, whereas the majority ( $81 \%$ and $64 \%$, respectively) of the production-oriented class agreed with them (Fig. 4). Multiple use of peatlands was also agreed by the majority $(76 \%)$ of current use supporters, whose opinions usually lie between those of the environmentalists and the production- 
Table 4. Results of the 3-class latent class model (LCM) including opinions on the ecosystem services of peatlands as explanatory variables for class membership. The class membership coefficients for Class 3 were fixed in order to identify the remaining coefficients. Number of respondents $=712$.

\begin{tabular}{|c|c|c|c|c|c|c|}
\hline & \multicolumn{2}{|c|}{$\begin{array}{c}\text { Class 1: } \\
\text { Environmentalist }\end{array}$} & \multicolumn{2}{|c|}{$\begin{array}{c}\text { Class 2: } \\
\text { Production-oriented } \\
\end{array}$} & \multicolumn{2}{|c|}{$\begin{array}{c}\text { Class 3: } \\
\text { Current use supporter }\end{array}$} \\
\hline & Coeff. & Stand. error & Coeff. & Stand. error & Coeff. & Stand. error \\
\hline Timber $^{+}$ & $* * *-1.181$ & 0.197 & $* * 0.347$ & 0.155 & -0.153 & 0.259 \\
\hline Timber $^{-}$ & -0.458 & 0.459 & $* * *-1.494$ & 0.300 & $* * *-3.064$ & 0.647 \\
\hline Peat $^{+}$ & $* * *-2.130$ & 0.163 & $* * * 1.013$ & 0.097 & -0.199 & 0.198 \\
\hline Peat $^{-}$ & $* * * 2.656$ & 0.231 & $* * *-1.338$ & 0.158 & 0.430 & 0.274 \\
\hline Protection & $* * 0.496$ & 0.198 & $* * * 0.539$ & 0.154 & $* * * 0.748$ & 0.251 \\
\hline Restor $^{+}$ & $* * * 1.478$ & 0.173 & -0.067 & 0.128 & -0.097 & 0.177 \\
\hline Restor $^{-}$ & -0.173 & 0.258 & $* * *-0.638$ & 0.171 & -0.204 & 0.269 \\
\hline Intercept & 0.179 & 0.243 & 0.212 & 0.176 & $* * * 2.318$ & 0.286 \\
\hline \multicolumn{7}{|l|}{$\begin{array}{l}\text { Class membership } \\
\text { parameters }\end{array}$} \\
\hline Intercept & $* * *-0.956$ & 0.317 & -0.254 & 0.200 & & \\
\hline Employment and income & $* * *-0.878$ & 0.199 & 0.074 & 0.242 & & \\
\hline Hydrological problems & $* * 0.388$ & 0.171 & -0.237 & 0.144 & & \\
\hline Energy source & $* * *-0.928$ & 0.149 & $* * 0.506$ & 0.224 & & \\
\hline Species and habitats & $* * * 1.108$ & 0.209 & -0.128 & 0.168 & & \\
\hline Recreation & $* 0.318$ & 0.171 & -0.215 & 0.143 & & \\
\hline Class probabilities & 0.636 & & 0.197 & & 0.167 & \\
\hline RsqAdj & 0.476 & & & & & \\
\hline Log-likelihood & -2407.935 & & & & & \\
\hline $\mathrm{AIC}$ & 1.164 & & & & & \\
\hline BIC & 1.218 & & & & & \\
\hline
\end{tabular}

oriented class. The production-oriented class showed most disagreement ( $42 \%$ of respondents in the class), toward the statement proposing that peatlands have a right to exist without utilization.

\section{Peatlands and personal life}

The respondents were asked how peatlands relate to their personal life. The environmentalist and current use supporter classes were characterized by the fact that their childhood home was not typically located close to peatlands compared with the production-oriented class, which was the reference class in this analysis (Table 6). The work of respondents in the environmentalist and current use supporter classes was less typically related to peatlands, whereas they were more active in picking berries in peatlands. Respondents belonging to the environmentalist class were more likely members of a conservation league and they were more likely to use peatlands for recreation and well-being than respondents in the two other classes.

\section{DISCUSSION AND CONCLUSIONS}

Our results indicate that the respondents had heterogeneous preferences regarding peatland use. Using the LCM we identified three classes of respondents, in which
Fig. 4. Opinions on the significance of nature and peatlands in the three classes of respondents, significant in the latent class model (LCM). Number of respondents $=712$.

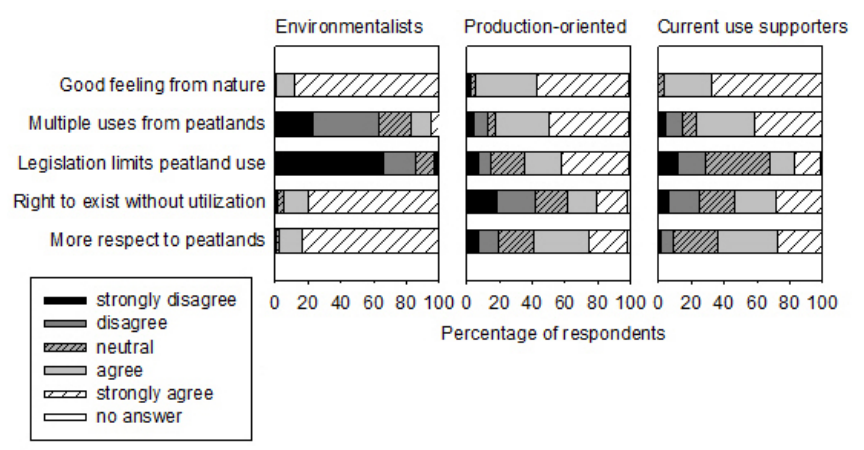

environmentalists emphasized ecological and environmental values of peatlands, production-oriented class preferred an increase in the commercial use of peatlands, and the current use supporters were an intermediate class showing a preference for the present land use policy. The result reflects 
Table 5. Results of the 3-class latent class model (LCM) including opinions on the significance of nature and peatlands as explanatory variables for class membership. The class membership coefficients for Class 3 were fixed in order to identify the remaining coefficients. Number of respondents $=712$.

\begin{tabular}{|c|c|c|c|c|c|c|}
\hline & \multicolumn{2}{|c|}{$\begin{array}{c}\text { Class 1: } \\
\text { Environmentalist }\end{array}$} & \multicolumn{2}{|c|}{$\begin{array}{c}\text { Class 2: } \\
\text { Production-oriented } \\
\end{array}$} & \multicolumn{2}{|c|}{$\begin{array}{c}\text { Class 3: } \\
\text { Current use supporter }\end{array}$} \\
\hline & Coeff. & Stand. error & Coeff. & Stand. error & Coeff. & Stand. error \\
\hline Timber $^{+}$ & $* * *-1.182$ & 0.229 & $* * * 0.437$ & 0.147 & -0.147 & 0.210 \\
\hline Timber $^{-}$ & -0.735 & 0.503 & $* * *-1.564$ & 0.297 & $* * *-2.498$ & 0.502 \\
\hline Peat $^{+}$ & $* * *-2.07$ & 0.166 & $* * * 1.038$ & 0.097 & $* *-0.380$ & 0.168 \\
\hline Peat $^{-}$ & $* * * 3.037$ & 0.263 & $* * *-1.153$ & 0.149 & 0.166 & 0.216 \\
\hline Protection & $* * * 0.659$ & 0.231 & $* * * 0.622$ & 0.145 & $* * * 0.625$ & 0.198 \\
\hline Restor $^{+}$ & $* * * 1.584$ & 0.188 & -0.077 & 0.127 & 0.182 & 0.150 \\
\hline Restor $^{-}$ & -0.126 & 0.280 & $* * *-0.715$ & 0.163 & -0.241 & 0.219 \\
\hline Intercept & 0.445 & 0.279 & $* 0.288$ & 0.167 & $* * * 1.900$ & 0.227 \\
\hline \multicolumn{7}{|l|}{$\begin{array}{l}\text { Class membership } \\
\text { parameters }\end{array}$} \\
\hline Intercept & $* *-4.227$ & 2.127 & -2.104 & 1.450 & & \\
\hline Good feeling & $* 0.704$ & 0.400 & -0.046 & 0.270 & & \\
\hline Multiple uses & $* * *-1.033$ & 0.168 & -0.027 & 0.203 & & \\
\hline Legislation & $* * *-0.871$ & 0.188 & $* * * 0.851$ & 0.172 & & \\
\hline Right to exist & $* * * 0.847$ & 0.228 & -0.167 & 0.142 & & \\
\hline Respect & $* * * 0.768$ & 0.234 & -0.006 & 0.022 & & \\
\hline Class probabilities & 0.622 & & 0.194 & & 0.184 & \\
\hline RsqAdj & 0.478 & & & & & \\
\hline Log-likelihood & -2399.442 & & & & & \\
\hline AIC & 1.160 & & & & & \\
\hline BIC & 1.214 & & & & & \\
\hline
\end{tabular}

the present level of socioeconomic sustainability in the peatland use among the respondents. Therefore, roughly one third is estimated to be satisfied with the present situation of peatland use.

It is important to notice that the response rate was quite low in the mail-based survey, and the web-based survey was openly available, which makes selection bias a concern in this study. Regarding the type of residential area of respondents, our sample was quite representative of the average population in northern Finland. In contrast, respondents' education and salary levels were higher in this study than in the study region in general. This is not a surprise because highly educated people tend to answer questionnaires more often than those with less education (Birol and Cox 2007, Westerberg et al. 2010). Also the proportion of landowners was higher in this study than on average in the region. Given the socioeconomic and attitudinal profiles of the three classes, we suggest that the environmentalist and production-oriented classes present more extreme opinions toward peatland use, whereas the general public, the majority of which did not answer the questionnaire, apparently has no strong opinions. The closest class to the general public in our data might be the current use supporters, but because the land ownership and the proportion of agricultural and forestry entrepreneurs were higher in this class than in the average population, this group was also slightly biased. Sending reminders to people receiving questionnaires might have decreased the selection bias somewhat.

Increasing information on the deterioration of peatland habitats and public debates on peatland use have raised a need to consider all elements of sustainability in peatland planning (Joosten and Clarke 2002). Conflicts of interest, observed through the grouping of respondents in our study, place a remarkable challenge for fitting together multiple needs subjected to the same ecosystem. Each party may concentrate on maximizing one land-use option without considering possibilities of other options (de Groot 2006). At first glance, our results support the conventional thought of urbanized elitists versus lower educated people living in the country. The environmentalist class, characterized as highly educated people living most typically in cities, preferred the complete cessation of peat production, whereas the people in the production-oriented class, whose personal lives were connected to peatland through work, and who most typically lived in rural communities, preferred the increase in peat production area. However, most respondents visited peatlands 
Table 6. Results of the 3-class latent class model (LCM) including factors on the relationships of peatlands to respondents' personal lives as explanatory variables for class membership. The class membership coefficients for Class 2 were fixed in order to identify the remaining coefficients. Number of respondents $=712$.

\begin{tabular}{|c|c|c|c|c|c|c|}
\hline & \multicolumn{2}{|c|}{$\begin{array}{c}\text { Class 1: } \\
\text { Environmentalist }\end{array}$} & \multicolumn{2}{|c|}{$\begin{array}{c}\text { Class 2: } \\
\text { Production-oriented }\end{array}$} & \multicolumn{2}{|c|}{$\begin{array}{c}\text { Class 3: } \\
\text { Current use supporter }\end{array}$} \\
\hline & Coeff. & Stand. error & Coeff. & Stand. error & Coeff. & Stand. error \\
\hline Timber $^{+}$ & $* * *-1.314$ & 0.205 & $* * 0.389$ & 0.153 & 0.024 & 0.258 \\
\hline Timber ${ }^{-}$ & -0.437 & 0.479 & $* * *-1.599$ & 0.310 & $* * *-3.075$ & 0.611 \\
\hline Peat $^{+}$ & $* * *-2.091$ & 0.164 & $* * * 1.022$ & 0.099 & -0.244 & 0.180 \\
\hline Peat $^{-}$ & $* * * 2.840$ & 0.240 & $* * *-1.157$ & 0.151 & 0.036 & 0.266 \\
\hline Protection & $* * 0.475$ & 0.207 & $* * * 0.608$ & 0.152 & $* * * 0.710$ & 0.250 \\
\hline Restor $^{+}$ & $* * * 1.542$ & 0.179 & -0.032 & 0.124 & -0.129 & 0.171 \\
\hline Restor $^{-}$ & -0.031 & 0.266 & $* * *-0.632$ & 0.162 & -0.407 & 0.271 \\
\hline Intercept & 0.271 & 0.253 & $* 0.208$ & 0.175 & $* * * 2.028$ & 0.278 \\
\hline \multicolumn{7}{|l|}{$\begin{array}{l}\text { Class membership } \\
\text { parameters }\end{array}$} \\
\hline Intercept & -0.175 & 0.275 & & & -0.264 & 0.328 \\
\hline Childhood home & $* * *-0.788$ & 0.273 & & & $*-0.562$ & 0.331 \\
\hline Work & $* * *-1.400$ & 0.264 & & & $* * *-0.956$ & 0.314 \\
\hline Well-being & $* * * 1.780$ & 0.274 & & & 0.457 & 0.316 \\
\hline Conservation league & $* * * 3.024$ & 0.431 & & & -0.007 & 0.032 \\
\hline Picking up berries & $* * * 0.780$ & 0.295 & & & $* * 0.793$ & 0.354 \\
\hline Class probabilities & 0.632 & & 0.191 & & 0.177 & \\
\hline RsqAdj & 0.443 & & & & & \\
\hline Log-likelihood & -2557.078 & & & & & \\
\hline AIC & 1.235 & & & & & \\
\hline $\mathrm{BIC}$ & 1.289 & & & & & \\
\hline
\end{tabular}

actively, which reflects a close connection to peatlands irrespective of the class and residential area.

Our results also showed shared views between stakeholder groups, and these shared views are crucial for building consensus and solving conflicts (Williams et al. 1998). All three classes showed a preference toward the increase of peatland protection area, while they simultaneously disagreed on the reduction of the peatland restoration area. Hence, there was a common agreement on the ecological values of peatlands and common support toward new management methods such as restoration. According to the review by Young et al. (2005), people do not usually object to conserving biodiversity, providing it does not conflict with personal or institutional goals. The fact that the shared views were found in the opinions toward the protection and restoration, but not the multiple uses of peatlands (disagreed on by environmentalists), actually reflects stricter, more purist attitudes toward peatland use among the environmentalists compared with the other two classes. Still, even the environmentalists were likely to agree on the current timber production level, indicating that the division between environmentalists and other groups was not straightforward.
The concept of ecosystem services provides a useful framework for land use planning, although there are still questions in the definition, quantification, and valuing of ecosystem services (de Groot et al. 2010). Of the seven ecosystem services considered, five were significant to explain the class memberships in the LCM: provisioning (employment and income, energy source), regulating (hydrological problems), supporting (species and habitats), and cultural (recreation) services. These ecosystem services had apparently different impacts on respondents' well-being. For example, despite the fact that hydrological problems were considered important by over half of the respondents in all classes and all respondents were active users of peatlands, production-oriented and current use supporter classes accepted the trade-off between the provisioning services and the other ecosystem services. Peat energy production occurs in remote regions with high unemployment rates. Perhaps for this reason, respondents in the production-oriented and current use supporter classes, among whom the most common residential area was rural communities, considered employment and income the most important ecosystem service. Two regulating ecosystem services, i.e., flood risk reduction and carbon sequestration, were generally highly 
valued ecosystem services, but the opinions toward them were similar across the respondent classes. These ecosystem services are quite difficult to see and experience in practice. Although Finland regularly encounters floods, they are considerably less dramatic compared to floods further south in Europe, where the loss of life and substantial economic damage has occurred several times during the recent decades (Hajat et al. 2005). For example, in the study by Birol et al. (2009) the flood risk reduction was a more highly valued management attribute than biodiversity conservation and recreational access.

Opinions toward ecosystem services may reflect both their direct and indirect impacts on people's well-being. Our results suggest that environmentally minded people, who are likely to consider the indirect use values and existence values as important, are less willing to make trade-offs between ecosystem services than those who emphasize direct use values. One reason behind the difference may be the availability of substitutes that makes the trade-offs casespecific. For example, if substitute sites are available for recreation, and the harmful effects of provisioning services to the environment are not considered to exceed a critical threshold, the trade-off may be accepted by people who emphasize direct use values. It is known that there may be substitutes to obtain conventional natural resources, such as berries, fish, and game, but they are not substitutes in terms of ecosystem functions (Farber et al. 2002). This difference is apparently recognized by people who intrinsically value environmental and natural resources highly. People whose livelihood, or the economic viability of their home territory, depends on the productive use of the resource at hand are likely to place a higher value on provisioning services than on cultural services. Still, even they are known to support the protection of their environment (see Haila 2012). As peatland restoration occurs in commercially unproductive peatlands, it improves both the use and existence values without reducing provisioning services. Therefore, restoration is commonly accepted by the public, in contrast to management options that involve clear trade-offs between ecosystem services.

We conclude that revealing trade-offs that people are willing to accept can enhance sustainable land use planning. Understanding the factors behind people's land use preferences is important because it helps the decision makers convey the reasons behind their decisions in a way that the general public understands. In implementing land-use strategies, such as the Finnish Government Program for the Sustainable Use of Mires and Peatlands, it may be unrealistic to expect a solution on peat production that all interest groups would completely accept. It is therefore important to openly justify the decisions with facts. For example, peat production should be justified by regional economic effects, or alternatively prohibit it using clear environmental arguments.
It must be remembered, however, that conflicts in themselves are not necessarily a negative thing, because they may highlight problems, increase understanding, and promote the creation of sustainable solutions (Young et al. 2005).

${ }^{[1]}$ The design was generated using NGene 1.0. However, we manually changed alternatives between two choice sets, because in testing the questionnaire respondents considered one choice set as prejudiced contrasting too much production and conservation.

${ }^{[2]}$ The classification for residential area was $1=$ rural area; $2=$ city or town, $<20,000$ inhabitants; $3=$ city or town, 20,000 100,000 inhabitants; 4 = city or town, > 100,000 inhabitants. However, we treated the residential area as a continuous variable in the analysis to reduce the number of estimated parameters. We also tested dummy variables, but the results were qualitatively similar to those obtained when using the continuous variable. The same applies also to the household monthly income which was classified into six ordinal categories in the questionnaire.

${ }^{[3]}$ We used NLOGIT 4.0 in the estimation. The reference class is determined endogenously in the estimation, and therefore, the reference class varies between different model specifications as will be seen later. Notice that our results are robust, because the same three classes can be identified from the all model specifications.

Responses to this article can be read online at: http://www.ecologyandsociety.org/issues/responses. $\mathrm{php} / 5496$

\section{Acknowledgments:}

We are grateful to Mikko Moilanen and Veijo Leiviskä from the Finnish Forest Research Institute, Matti Tapaninen from Metsähallitus, Niilo Piisilä from the Finnish Forestry Centre, and Ismo Karhu from Council of Oulu Region for helping us to choose the attributes and their levels in CE. We also thank Anna Piirainen and Johanna Kesti from the Department of Economics, University of Oulu, for assistance in conducting the survey. Irene Murtovaara is acknowledged for carrying out the layout of the mail questionnaire, and Sanna Hyvärinen for programming the web-based survey, both at the Finnish Forest Research Institute. Funding from the EU agricultural fund and the Finnish Forest Research Institute is gratefully acknowledged.

\section{LITERATURE CITED}

Balmford, A., A. Bruner, P. Cooper, R. Costanza, S. Farber, R. E. Green, M. Jenkins, P. Jefferiss, V. Jessamy, J. Madden, K. Munro, N. Myers, S. Naeem, J. Paavola, M. Rayment, S. 
Rosendo, J. Roughgarden, K. Trumper, and R. K. Turner. 2002. Economic reasons for conserving wild nature. Science 297:950-953.

Birol, E., and V. Cox. 2007. Using choice experiments to design wetland management programmes: the case of Severn Estuary Wetland, UK. Journal of Environmental Planning and Management 50:363-380. http://dx.doi.org/10.1080/096405$\underline{60701261661}$

Birol, E., N. Hanley, P. Koundouri, and Y. Kountouris. 2009. Optimal management of wetlands: quantifying trade-offs between flood risks, recreation, and biodiversity conservation. Water Resources Research 45(11). http://dx.doi. org/10.1029/2008WR006955

Birol, E., K. Karousakis, and P. Koundouri. 2006. Using a choice experiment to account for preference heterogeneity in wetland attributes: the case of Cheimaditida wetland in Greece. Ecological Economics 60:145-156. http://dx.doi. org/10.1016/j.ecolecon.2006.06.002

Boxall, P. C., and W. L. Adamowicz. 2002. Understanding heterogeneous preferences in random utility models: a latent class approach. Environmental and Resource Economics 23:421-446. http://dx.doi.org/10.1023/A:1021351721619

Boyer, T., and S. Polasky. 2004. Valuing urban wetlands: a review of non-market valuation studies. Wetlands 24:744-755. http://dx.doi.org/10.1672/0277-5212(2004)024[0744:VUWARO] 2.0.CO;2

Brander, L. M., R. J. G. M. Florax, and J. E. Vermaat. 2006. The empirics of wetland valuation: a comprehensive summary and a meta-analysis of the literature. Environmental and Resource Economics 33:223-250. http://dx.doi.org/10.1007/ s10640-005-3104-4

Carlsson, F., P. Frykblom, and P. Liljenstolpe. 2003. Valuing wetland attributes: an application of choice experiments. Ecological Economics 47:95-103. http://dx.doi.org/10.1016/ j.ecolecon.2002.09.003

Chapman, S., A. Buttler, A.-J. Francez, F. Laggoun-Défarge, H. Vasander, M. Schloter, J. Combe, P. Grosvernier, H. Harms, D. Epron, D. Gilbert, and E. Mitchell. 2003. Exploitation of northern peatlands and biodiversity maintenance: a conflict between economy and ecology. Frontiers in Ecology and the Environment 1:525-532. http:// dx.doi.org/10.1890/1540-9295(2003)001[0525:EONPAB]2.0. $\mathrm{CO} ; 2$

Collier, M. J. 2011. Incorporating socio-economic factors into restoration: implications from industrially harvested peatlands. Restoration Ecology 19:559-563. http://dx.doi. org/10.1111/j.1526-100X.2011.00794.X

Collier, M. J., and M. Scott. 2008. Industrially harvested peatlands and after-use potential: understanding local stakeholder narratives and landscape preferences. Landscape Research 33:439-460. http://dx.doi.org/10.1080/01426390801948406

Collier, M. J., and M. Scott. 2010. Focus group discourses in a mined landscape. Land Use Policy 27:304-312. http://dx. doi.org/10.1016/j.landusepol.2009.04.001

Costanza, R., R. d'Arge, R. de Groot, S. Farber, M. Grasso, B. Hannon, K. Limburg, S. Naeem, R.V. O'Neill, J. Paruelo, R.G. Raskins, P. Sutton, and M. van den Belt. 1997. The value of the world's ecosystem services and natural capital. Nature 387:253-260. http://dx.doi.org/10.1038/387253a0

de Groot, R. 2006. Function-analysis and valuation as a tool to assess land use conflicts in planning for sustainable, multifunctional landscapes. Landscape and Urban Planning 75:175-186. http://dx.doi.org/10.1016/j.landurbplan.2005.02.016

de Groot, R., R. Alkemade, L. Braat, L. Hein, and L. Willemen. 2010. Challenges in integrating the concept of ecosystem services and values in landscape planning, management and decision making. Ecological Complexity 7:260-272. http://dx. doi.org/10.1016/j.ecocom.2009.10.006

Farber, S. C., R. Costanza, and M. A. Wilson. 2002. Economic and ecological concepts for valuing ecosystem services. Ecological Economics 41:375-392. http://dx.doi.org/10.1016/ S0921-8009(02)00088-5

Finnish Forest Research Institute. 2011. Finnish statistical yearbook of forestry 2011 Finnish Forest Research Institute, Vantaa, Finland.

Haila, Y. 2012. Genealogy of nature conservation: a political perspective. Nature Conservation 1:27-52. http://dx.doi. org/10.3897/natureconservation.1.2107

Hajat, S., K. L. Ebi, R. S. Kovats, B. Menne, S. Edwards, and A. Haines. 2005. The human health consequences of flooding in Europe: a review. Extreme Weather Events and Public Responses 4:185-196. http://dx.doi.org/10.1007/3-540-28862-7 18

Joosten, H., and D. Clarke. 2002. Wise use of mires and peatlands - background and principles including a framework for decision-making. International Mire Conservation Group and International Peat Society, Greifswald, Germany and Jyväskylä, Finland.

Laine, A.M., M. Leppälä, O. Tarvainen, M.-L. Päätalo, R. Seppänen, and A. Tolvanen. 2011. Restoration of managed pine fens: effect on hydrology and vegetation. Applied Vegetation Science 14:340-349. http://dx.doi.org/10.1111/ j.1654-109X.2011.01123.X

Louviere, J. J., D. A. Hensher, and J. D. Swait. 2000. Stated choice methods: analysis and applications. Cambridge University Press, Cambridge, UK. http://dx.doi.org/10.1017/ CBO9780511753831 
Morrison, M., J. Bennett, and R. Blamey. 1999. Valuing improved wetland quality using choice modeling. Water Resources Research 35:2805-2814. http://dx.doi. org/10.1029/1999WR900020

Official Statistics of Finland. 2009. Distribution of incomes in Finland. [Title translated from the Finnish]. Official Statistics of Finland, Helsinki, Finland. [online] URL: http:// www.stat.fi/til/tjt/2009/tjt 2009 2011-05-20 tau 007 fi.html

Official Statistics of Finland. 2010. Students aiming at degrees in Finland. [Title translated from the Finnish]. Official Statistics of Finland, Helsinki, Finland. [online] URL: http:// www.stat.fi/til/opiskt/2011/opiskt_2011_2012-01-26_tau_001_fi. $\underline{\mathrm{html}}$

Official Statistics of Finland. 2011a. Population structure in Finland; sub-table: Northern Ostrobothnia. [Title translated from the Finnish]. Official Statistics of Finland, Helsinki, Finland. [online] URL: http://www.stat.fi/til/vaerak/tau.html ISSN=1797-5379 Helsinki

Official Statistics of Finland. 2011b. Statistics of agricultural and forestry entrepreneurs. [Title translated from the Finnish]. Official Statistics of Finland, Helsinki, Finland. [online] URL: http://tilastokeskus.fi/til/mmtal/

Selin, P. 1999. Industrial use of peatlands and the re-use of cut-away areas in Finland. [Title translated from the Finnish]. Dissertation. University of Jyväskylä, Finland.

Smith, M., D. de Groot, and G. Bergkamp. 2006. Pay: establishing payments for watershed services. International Union for Conservation of Nature, Gland, Switzerland. http:// dx.doi.org/10.2305/IUCN.CH.2006.WANI.4.en

Tarvainen, O., A. M. Laine, M. Peltonen, and A. Tolvanen. 2012. Mineralization and decomposition rates in restored pine fens. Restoration Ecology, in press. http://dx.doi.org/10.1111/ j.1526-100X.2012.00930.x

Westerberg, V. H., R. Lifran, and S. B. Olsen. 2010. To restore or not? A valuation of social and ecological functions of the Marais des Baux wetland in Southern France. Ecological Economics 69:2383-2393. http://dx.doi.org/10.1016/j. ecolecon.2010.07.005

Williams, P. W., R. W. Penrose, and S. Hawkes. 1998. Shared decision-making in tourism and land use planning. Annals of Tourism Research 25:860-889. http://dx.doi.org/10.1016/ S0160-7383(98)00037-1

Young, J., A. Watt, P. Nowicki, D. Alard, J. Clitherow, K. Henle, R. Johnson, E. Laczko, D. MacCracken, S. Matouch, J. Niemelä, and C. Richards. 2005. Towards sustainable land use: identifying and managing the conflicts between human activities and biodiversity conservation in Europe. Biodiversity and Conservation 14:1641-1661. http://dx.doi. org/10.1007/s10531-004-0536-Z
Zedler, J. B., and S. Kercher. 2005. Wetland resources: status, trends, ecosystem services, and restorability. Annual Review of Environment and Resources 30:39-74. http://dx.doi. org/10.1146/annurev.energy.30.050504.144248 